\title{
A Development New Generation of Professional Teachers, Sripatum University
}

\author{
S. Sinjindawong
}

\begin{abstract}
Teaching and Learning could be used to coach for development a new professional teacher. The objectives of this study were 1) to create professional teacher network in teaching and learning, 2) to have activities for professional teachers' development, 3) to publish academic outcome such as knowledge and teaching techniques of new generation teachers. The area of these studies was 2 coaches who were recognized in teaching and learning, 10 selected teachers from persons who applied for this development project. There are 7 steps in this process as: 1) to select coaches with recognized and successful, 2) to advertise the project for the qualified teachers' audition, 3) to develop new generation of teachers for 2 teams, 4) to report the progress of each team coach, 5) to collect the results from new generation of teacher, 6) to share knowledge and techniques for new generation of teachers, 7) to recommend the innovative teacher award. This is 9 months' project for development new generation of teachers.

The Results of this study found that: The Professional teacher's network in teaching and learning is in all faculties, 20 teachers apply to the project with audition and interview by the committee, the committee consider for their development needs with positive attitude and thinking. The first team with one coach concerns with instructional design and the other team concerns with creative digital textbooks and supplementary materials. Moreover, Sripatum University arranges teaching and learning forum 2015 for publishing academic knowledge and presenting their teaching and learning techniques.
\end{abstract}

Index Terms - New generation, teacher, professional teacher.

\section{INTRODUCTION}

Since an education system is a part of human development, and educational quality mentions in general. The concept of educational quality in the $21^{\text {st }}$ Century, [1] said that, "The good education for new generation will differ in the past, quality of education will be change learning style and role of teacher will be change follow a nature of learning student".

The professional teacher must change with relation to [2], he found that the professional teacher must change to be a good professional teacher, a teacher should have knowledge and skills in 1) Working with equitability for all students by respecting diversity of each learner, 2) Being able to apply and communicate knowledge as practiced in careers for active learners, 3) Applying knowledge of curriculum, instruction, principles of learning and implement programs for all learners, 4) Collaborating with learners, parents, communities and social agencies, 5) Appreciating the principles, ethics and social responsibilities of the professional teachers and 6) Contributing personal teaching techniques to the faculty level

Manuscript received November 30, 2015; revised March 1, 2016.

S. Sinjindawong is with the Sripatum University, Thailand (e-mail: sirinthorn.si@spu.ac.th). and university level. Moreover, [3] described a model of teachers' attitudes and perceptions. The model of teacher change presents an alternative approach. This model can change according to teachers' attitudes and beliefs of improvements in students' learning. A new instructional approach uses new teaching materials or curricula or simply a modification in teaching procedures or classroom activities.

Teaching and Learning focuses on students' outcomes in four areas: 1) Core Subjects, 2) Learning and Innovation Skills (Creativity and Innovation, Critical Thinking and Problem Solving, and Communication and Collaboration), 3) Information, Media and Technology Skills (Information Literacy, Media Literacy, ICT Literacy), and 4) Life and Career Skills [4].

Therefore, it is essential for teachers to develop their students. Teachers need to modify and change the teaching method according to changes in our society, technology and students' learning. Teachers have to change their roles as mentors. The way of teaching has changed, so the students can search for themselves for information and gain knowledge. Therefore, they can apply their knowledge and skills for their understanding themselves and learning significantly.

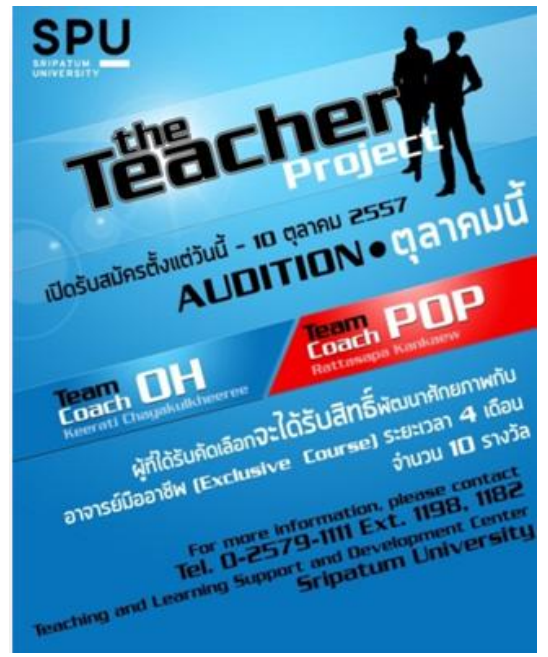

Fig. 1. Advertisement of the teachers' project.

Ref. [5] found that there were three sections in the professional development program which were: 1) Teacher, who is the learner in the system, 2) The facilitators, who guides teachers as they construct new knowledge and practices, and 3) The context which the professional development occurs. Professional development program has three phases, as follows: Phase1: activity focuses on individual the professional development program with a single site, teachers as learners with two elements, Phase 2: research study aims a single professional development with two facilitators and two sites, and Phase 3: compare multiple 
professional development relationships in all four elements.

The objectives of this study were as follows:

1) To create professional teacher network in teaching and learning by a coach who is recognized and successful in teaching and learning.

2) To have activities for professional teachers' development.

3) To publish academic outcomes such as knowledge and teaching techniques of a new generation teachers.

"The Teachers' Project" is a project for developing on the next generation of teachers. Therefore, this project by a mentor or coach develops the teachers' potential of teaching and learning. The coach would encourage and inspire to members in each team with new knowledge and teaching techniques.

\section{METHODOLOGY}

\section{A. The Group Study}

The area of these studies with two coaches, who were recognized in teaching and learning, 20 teachers applied for the project with auditions and interviews by the committee.

\section{B. The Process for Development}

There are seven steps in the process for development as follows:

1) To select coaches who are recognized and successful in teaching and learning.

Qualifications:

- Over 10 years teaching experience.

- Have teaching award at the institutional level or the national level.

- Have positive attitude in teaching.

- Have, helped and support other teachers.

2) To advertise the project for the qualified teachers' audition (see Fig. 1).

Applicants' Qualifications:

- Have self-development in teaching.

- Devote time for development.

- Have a positive attitude to the coach and also in teaching.

- Achieve their goal for development.

3) To develop new a generation of teachers for two teams (see Fig. 2).

- The first team: Coach Pop who is an expert in Knowledge, Attribute, and Practice (KAP) for professionals.

- The second team: Coach Oh who is an expert in textbook and supplementary materials.

4) Two periods to report the progress of each team coach.

- The first period, after four months, report to the committee or dean.

- The second period, finish the project within nine months and report to publish in the teaching and learning forum.

5) To collect the results from new generation of teachers.

Teaching and Learning Support and Development Center (TLC) monitors all processes, facilitate and solve the problems for progressing.
6) To share knowledge and techniques for the new teachers' generation development.

On 22 July, 2015, TLC -SPU published results of the teachers' project at "Teaching and Learning Forum 2015 for sharing experiences in developing teachers from each team.

7) To acknowledge "The Innovative Teacher Award"

There are two levels of the acknowledgement for "The Innovative Teacher Award" which are good and excellent.

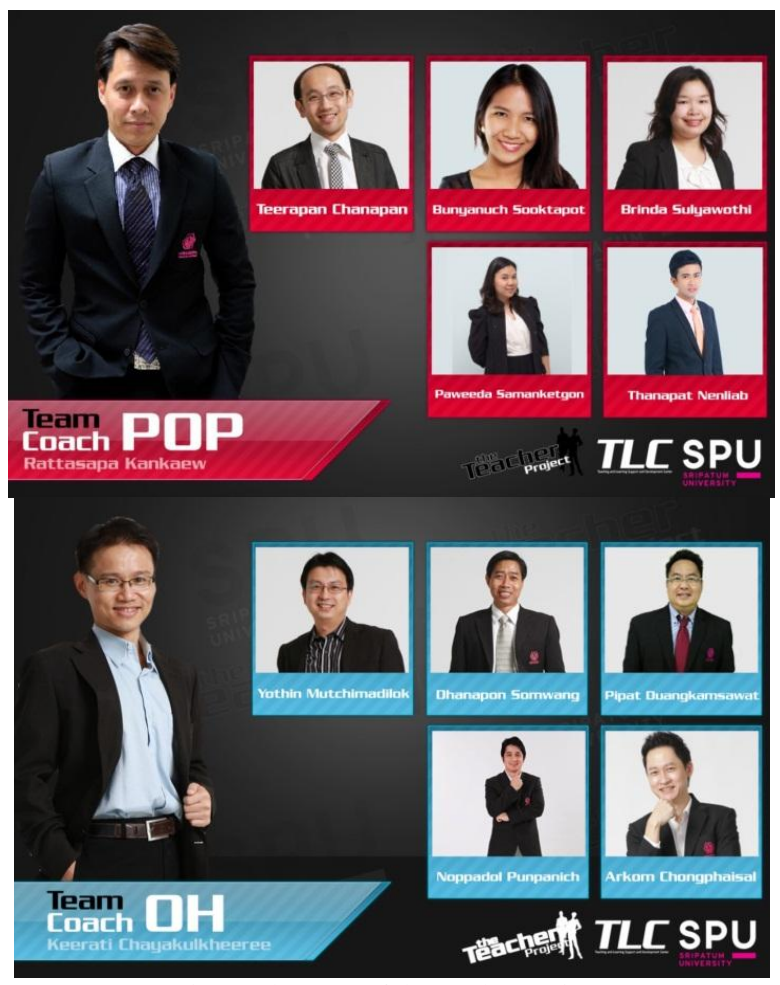

Fig. 2. The team of the teacher project.

\section{RESULTS}

This research is to develop a new generation of teachers which is presented in three parts:

Part 1: The Professional teacher's network in teaching and learning

The coach's qualifications someone who is recognized and successful in teaching and learning, this project is separated into two teams as follows:

Team1: Coach Pop: expert in presentation, media production and a video record presentation with explain voice in practical subjects. Coach Pop uses a pilot teaching and learning model of video tutorials, use a social media strategy, and also e-learning for efficiency in teaching and learning as well.

The criteria for audition members' team: First of all, select teachers with a positive attitude. The purposes of this team are to "develop teachers for students, care in teaching, have good techniques, use good media and motivate students to attend classes".

Coach Pop has outstanding teaching techniques with his awards from the institution level and his experiences to train and develop to a new generation with expert skills and has been accepted by academic and professionals. He has received many awards as follows: The Best Teaching Award 2010 at the institution level, The Good Teaching Technique 
2012 (Thinking Based Learning on the critical thinking process), and The Director Honor of Dr. Suk Pukayaporn Awards 2013.

Coach Pop's Team consists of five teachers as follows: a teacher from the Advertising program, School of Communication Arts; a teacher from the Radio and television program, School of Communication Arts; two teachers from Tourism Management program, School of Liberal Arts; and a teacher from Marketing program, School of Business Administration.

Team 2: Coach Oh: expert in application of electrical hardware computers in engineering, teaching and learning research in efficiency learning such as e-Learning replacement and creating quality textbooks and supplementary materials.

Coach Oh has produced an outstanding textbook in electrical power and has been accepted by academic and professionals. He has received many awards as follows: The Best Paper Award in $27^{\text {th }}$ Electrical Engineering Thailand Conference 2004, The Academic Honor of Dr. Suk Pukayaporn Awards 2009, The Academic Award in Science and Technology of The Association of Private Higher Educations Institutions of Thailand 2010, The Good Teaching Technique 2012 (Thinking Based Learning on mathematical thinking skills), and The Senior Teacher Award in Science and Technology of The Association of Southeast Asian Institutions of Higher Learning 2013.

Coach Oh's team consists of one teacher from five schools as follows: Civil Engineering program, School of Engineering, Humanity and Social Science, Institution of General Education, Information and Communication Technology, School of Information Technology, Doctor of Business Administration, Graduate College of Management, and Graphic Design, School of Digital Media.

\section{Part 2: Development of Teachers to be Professional}

- First step, after audition

Each coach gives an orientation to all team members, and then each member has to set a plan of self-development.

- Team Coach Pop will prepare teachers for instructional design in the next semester.

Team Coach Oh will prepare teachers for creating textbooks for their own subjects.

- Follow up on the progress of each team and visit classes.

Five steps of Coach Pop's process

1) Introduce a new way of teaching - suggest teaching techniques and give textbook.

2) Break the ice and be supportive - clarify the gap between coach and team.

3) Apply knowledge and techniques - explain and demonstrate examples of teaching techniques.

4) Adjust and work together - instructional design by coach and individual person.

5) Re-thinking on how to be a good teacher and what you want to be? - rewrite work to be better.

Strategy of the Coach

1) Leader - follow the coach.

2) Manager - set time period and monitor team.

3) Admin - communicate by using social media.

4) Planner - set plan for individual improvement.
5) Communicator - share good things on Facebook Group and update diary record.

\section{Coach is KM Manager}

Coach Pop -2015 "Being a coach is much more than an honor it's an opportunity to make a difference."

TABLE I: SUMMARY ATTENTION FROM MEMBERS IN COACH POP' TEAM

\begin{tabular}{llll}
\hline \hline \multicolumn{1}{c}{ Brinda } & \multicolumn{1}{c}{ Paweeda } & \multicolumn{1}{c}{ Teerapan } & \multicolumn{1}{c}{ Bunyanuch } \\
\hline Time- time & Open - open & Learning - & Learn - learn to \\
management & mind and adjust & learn & teach and prepare \\
Attraction- how & attitude & unknown & instructional \\
to be potential & Accept receive & and adjust & Think - think new \\
teacher, and how & new things & knowledge & things for students \\
to attract & Adjust - update & Instruction & Idea - get new \\
students to use & new techniques & Design - & ideas and share \\
e-learning & for oneself & re-design & with the team \\
Project Based- & Inquiry Based & course into & Creative - invent \\
"Tarad.com & -search for new & standard & new media for the \\
Project" online & knowledge for & Time plan & course \\
sale & suitable students & for & Do-adjust \\
commodities. & Goals - set & improvement & instructional \\
Innovation- & future targets to & Action - & design for next \\
teach new things & professional & done and & semester \\
and push new & & improved as & \\
ideas & & planed & \\
Professional- & & Project - & \\
self-development & & set new & \\
and build & & project for & \\
professional & & students & \\
students & & & \\
& & &
\end{tabular}

The summary of Coach Pop's team showed was that the team could learn new things and design courses for outcome based for students, and at the same time self-develop to be professional. Bring knowledge to practice, re-instructional design from content, moral knowledge, apply and deploy, give suggestions, control the practice of the instructional design, goals, new media, and experiment in teaching.

Attitude will change to be a good and professional teacher. (see Table I).

Coach Oh's Team, the purpose of this teacher development team is to produce digital books and supplementary materials.

5 Steps of coach $\mathrm{Oh}$

1) Set target - make suggestions to the team and have a roadmap for applying academic title.

2) Prepare documents - provide documents that relate to a research such as a course syllabus.

3) Start writing - schedule and scoped for academic writing and start working.

4) Follow up on the progress - meet and present individual work progress and ask experts to give recommendations.

5) Review to be good and professional - adjust work to meet the criteria for applying for an academic title, and produce digital books and supplementary materials.

6) Coach Oh suggests how to write textbooks and supplementary materials for applying for an academic title.

The summary of coach Oh's team showed that they had set a roadmap for teachers to be an expert or apply for academic title, with the plan to prepare documents which include: textbooks, digital books and supplementary materials in expert subject. And then, two teachers from this project can start the process of applying for an academic title (see Table II). 
TABLE II: SUMMARY ATTENTION FROM MEMBERS IN COACH OH’ TEAM

\begin{tabular}{llll}
\hline \multicolumn{1}{c}{ Pipat } & \multicolumn{1}{c}{ Noppadol } & \multicolumn{1}{c}{ Dhnaphol } & \multicolumn{1}{c}{ Arkom } \\
\hline $\begin{array}{l}\text { Aim to approach } \\
\text { academic title and plan } \\
\text { to prepare academic } \\
\text { documents }\end{array}$ & $\begin{array}{l}\text { Aim to develop and } \\
\text { prepare instructional } \\
\text { documents, text books } \\
\text { and actually apply if the } \\
\text { classroom }\end{array}$ & $\begin{array}{l}\text { Aim to produce a } \\
\text { good text book } \\
\text { for the Buddhism } \\
\text { course }\end{array}$ & $\begin{array}{l}\text { Aim to write a book, but don't know Aim to develop and prepare } \\
\text { how to write it. Coach suggests } \\
\text { recording voice and then } \\
\text { transferring it to text. Then can } \\
\text { instructional documents by } \\
\text { collect each part to be a book and a } \\
\text { text book }\end{array}$ \\
\hline \hline
\end{tabular}

Part 3: To Publish Academic Knowledge in Teaching and Learning Research of a New Generation of Teachers

Teaching and learning forum to publish experience from coaches and teams member on sub-themes " $\mathrm{O} n$ the next generation of teachers" on 22 July 2015 in auditorium1, Building no.11, Sripatum University.

Teachers are important people who are involved with the quality development of students. Teachers are the most important part to drive students and make it happen for students' graduation. Truly, our university has quality teachers who have knowledge, competence, experience, skills and qualifications in teaching in all curricula. But not only do the teachers have an educational background, but also have to be a good and professional teacher which are the keys points. Particularly, the world changes every day. Students are different from the past. Therefore, it is important for teachers to update and develop their teaching and learning. It is one important key success of the University's mission; Sripatum University has been set a Teaching and Learning Support and Development Center (TLC) in 2010 TLC sets the ongoing teacher development project. "The Teacher Project". We believe our teachers have individual potentiality. Many teachers think that they cannot do but they can do, they want a mentor or a coach for suggestions and to control something to work forward. Fortunately, there is a good coach. The outcome of the project for teacher development in this dimension makes their dream come true, they learn more and change the way they teach. Some can apply for academic title.

\section{CONCLUSION}

The results of this study found that: The professional teacher network in teaching and learning is aware of all faculties, 20 teachers applied to the project and were interviewed by the committee to search for the need for development. The teachers had a good attitude for self-development to be professional teachers.

\section{A. The Professional Teacher's Network in Teaching and Learning}

The qualification of coaches who are recognized and successful in teaching and learning and who had received awards about teaching and learning such as The Best Teaching Award or The Good Teaching Technique Award, and other award in teaching. The committee auditioned member for the teams. The criteria for auditioning members for each team, first of all to select a teacher with a positive attitude who wants to improve in self-development in teaching. The purposes of the team were to "develop teachers for students, care in teaching, have good technique, have good media, develop documents for teaching and motivate students to attend class." The professional teacher network in teaching and learning had from all faculties: Four teachers who were developed in professional practice and five teachers who were developed in producing digital books for teaching. The teacher development is related to [3] who describes a model of teacher change in teachers' attitudes and perceptions. The model of teacher change presents an alternative approach. The model changed in teachers' attitudes and beliefs of improvements in student's learning. A new instructional approach is used for new materials, curricula, or simply a modification in teaching procedures or classroom format.

\section{B. Develop Teachers to Professional}

The development of teacher to be professional, the first step after the audition by the team coach is to give the orientation to all the teachers, and then set a plan for individual development, and also select their goals that focus in two teams, as follows:

The first team would prepare teachers for instructional design in 2015 academic by using the strategy as follows: 1) Coach is a leader to adjust instruction and of which members can follow, 2) Coach is a manager to set a time period and monitor the team, 3) Coach is an administrator to coordinate with the team by using social media, 4) Coach is a planner to set plans for individual improvement, and 5) Coach is a communicator to share the good things on Facebook Group and update diary record.

The second team will prepare teachers for creating textbooks (digital textbooks) in their own subject by using the five steps as follows: 1) Set target for team members, suggest to team to create a roadmap for applying for an academic title,

2) Prepare supplementary materials for writing by providing documents that relate to research and a course syllabus, 3) Start writing a book, manage schedules, and scope for academic writing, and then start working, 4) Follow up on the progress by having a meeting, present work progress, and ask an expert to give recommendations and, 5) Review to be good and professional which is advised by coach to adjust the work to meet the criteria and produce a digital book.

The development of teacher professionalism is related to [6] "A sense of teacher professional identity and like teaching of student" education major had a high correlation. Five factors with high factor loadings as follows: 1) Role of teaching and learning 2) self as role model 3) sense of calling 4) sense of professional identity 5) professional growth as a teacher, results shows that student' education major from the Bachelor of Arts (Education) and Bachelor of Science (Education) programs had a positive of teaching. Graduation of teacher had an important misconception in informant for teacher educators as they continue to explore and develop during a preparation program.

\section{Publish Academic Knowledge in Teaching and}




\section{Learning Research of a New Generation Teacher}

Teaching and Learning forum is one way for publishing experiences from coaches and team members in sub-themes, "On the next generation of teachers" on 22 July 2015 in Auditorium 1, Building 11, Sripatum University. Teachers are important to drive students for their graduation. The world changes every day. Students are different from the past. Therefore, it is important to drive for teacher development. It is one of the key successes for the University's mission.

The purpose of the Teaching and Learning Forum is to share experience from coaches and team members in the next generation of teachers which is related to [2] The professional teacher must change to be a good teacher who will have knowledge and skills in 1) Working with an equitability for all students by respecting diversity of each learner, 2) Being able to apply and communicate knowledge as practiced in careers for active learners, 3) Applying knowledge of curriculum, instruction, principles of learning and implement programs to all learners, 4) Collaborating and partnerships with learners, parents, communities and social agencies, 5) Appreciating the principles, ethics and social responsibilities of professional teachers, and 6) Contributing personal teaching techniques at the faculty level and the university level. Moreover, related to [7] found that the Active Learning method could improve the learning process of teachers to provide the environmental learning for promoting the student's self-learning. The purpose of the teaching of active learning is a different way of partnership learning by teachers and students to create learning activities and technology all the time.

\section{RECOMMENDATIONS}

\section{A. Utilization of Research Results}

1) Apply a concept of teacher development into professional deploy to teacher development in all faculties in higher education.

2) Apply and use the considerations principles for teacher development for promoting teachers to achieve the goals by emphasizing the different person.

3) Apply a concept of the teachers' project by the coach to sacrifice, inspire and help for teachers' development to their profession.

4) Give awards and encourage morale for self-development, and change teaching methods and become a good teacher.

\section{THE NEXT RESEARCH}

1) Should study to build new coach instead senior coach for teacher network development to be professional.

2) Should do the research for building learning community in teaching and learning at the level internal and external institution.

3) Should do the research for operating the development of new teachers by preparing knowledge attitude and performance in effective teaching and learning.

\section{REFERENCES}

[1] W. Panich, Learning Pathways for Students in the $21^{\text {st }}$ Century, Bangkok: Sodsri-Saridwongso Foundation, 2011.

[2] M. G. Fullan, "The professional teacher why teachers must become change agents," Educational Leadership, vol. 50, no. 6, pp. 1-13, 1993.

[3] T. R. Guskey, "Professional development and teacher change," Teachers and Teaching: theory and Practice, vol.8, no. 3, pp. 381-391, 2002.

[4] A. R. Saavedra and V. D. Opfer, Teaching and Learning $21^{\text {st }}$ Century Skills: Lessons from the Learning Sciences. Rand Corporation, Asia Society, Partnership for Global Learning, 2012.

[5] H. Borko. "Professional development and teacher learning: Mapping the terrain," Educational Researcher, vol.33, no. 8, pp. 3-15, 2004.

[6] S. Chong, E. L. Low, and K. C. Goh. "Emerging professional teacher identity of pre-service teacher," Australian Journal of Teacher Education, vol. 36, no. 8, pp. 50-64, 2011.

[7] W. Phisonkunkasem, S. Sinjindawing, and W. Thaima, "The active learning models in higher education: A case study of the classroom at Sripatum University," APHEIT International Journal, vol. 3, pp. 18-27, 2014.

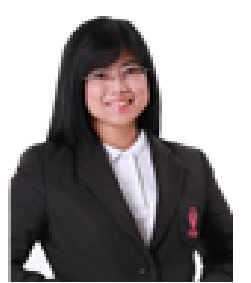

Sirinthorn Sinjindawong was born in Supanburi province, Thailand, on January 21, 1972. For educational background is the doctoral degree in educational measurement and evaluation, Faculty of Education Chulalongkorn University, Thailand in 2010 and the master degree in Educational Measurement, Srinakharinwirot University, Thailand and the bachelor degree in general science, Pranakorn Sri Ayutthaya Rajabhat University, Thailand.

She was teaching in research methodology course for Ph.D. students in educational administration, and project management and evaluation course for M.Ed. graduate program. And also, she was teaching undergraduate courses for research methodology to business, accounting, economy, and airline business students, bachelor program. She had 18 research projects She had received research fund from National Research Council of Thailand, that she was a plan director on the topic "Development of teacher at basic education level on the assessment of high level learning" and researcher fund in Thai Health Promotion Foundation 4 projects, and the Association of Private Higher Education Institutions of Thailand, too. She published some articles. 